\title{
PPAR $\gamma$ Recruitment to Active ERK during Memory Consolidation Is Required for Alzheimer's Disease-Related Cognitive Enhancement
}

\author{
Jordan B. Jahrling, ${ }^{1,2}$ Caterina M. Hernandez, ${ }^{1,2}$ Larry Denner, ${ }^{1,3,4,5,6}$ and Kelly T. Dineley ${ }^{1,2}$ \\ ${ }^{1}$ Mitchell Center for Neurodegenerative Diseases, Departments of ${ }^{2}$ Neurology and ${ }^{3}$ Internal Medicine, Division of Endocrinology, ${ }^{4} \mathrm{McC}$ Cy Stem Cells and \\ Diabetes Mass Spectrometry Research Laboratory, ${ }^{5}$ Sealy Center for Molecular Medicine, and ${ }^{~ I n s t i t u t e ~ f o r ~ T r a n s l a t i o n a l ~ S c i e n c e, ~ U n i v e r s i t y ~ o f ~ T e x a s ~}$ \\ Medical Branch, Galveston, Texas 77555
}

\begin{abstract}
Cognitive impairment is a quintessential feature of Alzheimer's disease (AD) and AD mouse models. The peroxisome proliferatoractivated receptor- $\gamma(\operatorname{PPAR} \gamma)$ agonist rosiglitazone improves hippocampus-dependent cognitive deficits in some AD patients and ameliorates deficits in the Tg2576 mouse model for AD amyloidosis. Tg2576 cognitive enhancement occurs through the induction of a gene and protein expression profile reflecting convergence of the PPAR $\gamma$ signaling axis and the extracellular signal-regulated protein kinase (ERK) cascade, a critical mediator of memory consolidation. We therefore tested whether PPAR $\gamma$ and ERK associated in protein complexes that subserve cognitive enhancement through PPAR $\gamma$ agonism. Coimmunoprecipitation of hippocampal extracts revealed that PPAR $\gamma$ and activated, phosphorylated ERK (pERK) associated in Tg2576 in vivo, and that PPAR $\gamma$ agonism facilitated recruitment of $\operatorname{PPAR} \gamma$ to pERK during memory consolidation. Furthermore, the amount of PPAR $\gamma$ recruited to pERK correlated with the cognitive reserve in humans with $\mathrm{AD}$ and in Tg2576. Our findings implicate a previously unidentified PPAR $\gamma$-pERK complex that provides a molecular mechanism for the convergence of these pathways during cognitive enhancement, thereby offering new targets for therapeutic development in $\mathrm{AD}$.
\end{abstract}

Key words: Alzheimer's; hippocampus; in vitro reconstitution; protein complex; transgenic

\section{Introduction}

Alzheimer's disease (AD) is a debilitating neurodegenerative disorder that manifests as cognitive impairment and brings with it a tremendous economic and social burden, as well as a tragic prognosis for increasing incidence in a burgeoning aging population (Thies and Bleiler, 2013). Many studies have suggested that a key causative factor in $\mathrm{AD}$ dementia is amyloid $\beta(\mathrm{A} \beta)$ derived from the amyloid precursor protein (Hsiao et al., 1996; Westerman et al., 2002; Sperling et al., 2011). Prompted by the realization that insulin resistance is another recognized risk factor in $\mathrm{AD}$ (van Himbergen et al., 2012) and that insulin resistance is a comorbidity factor in both diabetes and AD (Talbot et al., 2012), many

Received Sept. 19, 2013; revised Jan. 15, 2014; accepted Feb. 4, 2014.

Author contributions: J.B.J., C.M.H., L.D., and K.T.D. designed research; J.B.J. and C.M.H. performed research; J.B.J. and K.T.D. analyzed data; J.B.J., L.D., and K.T.D. wrote the paper.

This work was supported by the National Institutes of Health under Grant R01-AG031859 (to K.T.D. and L.D.). Additional funding was provided by the American Health Assistance Foundation, The Sealy Foundation for Biomedical Research, and a gift from J.W. Mohn (to K.T.D. and L.D.); by the Emmett and Miriam McCoy Foundation (to L.D.); and by the Cullen Trust for Health Care to the Mitchell Center. Behavioral testing was performed in the University of Texas Medical Branch at Galveston Rodent In Vivo Assessment Core directed by K.T.D. We thank Drs. Nicole Bjorklund and Giulio Taglialatela for generously providing the human tissue samples investigated herein. We also thank Wei Song for expert technical assistance and Ibdanelo Cortez for a number of insightful discussions.

The authors declare no competing financial interests.

Correspondence should be addressed to Dr. Kelly T. Dineley, 301 University Boulevard, Galveston TX 77555-0616. E-mail: ktdinele@utmb.edu.

DOI:10.1523/JNEUROSCI.4024-13.2014

Copyright $\odot 2014$ the authors $\quad 0270-6474 / 14 / 344054-10 \$ 15.00 / 0$ studies have investigated insulin sensitizer therapies as therapeutics for $\mathrm{AD}$ (Craft, 2012). A popular target is the nuclear receptor peroxisome proliferator-activated receptor- $\gamma(\operatorname{PPAR} \gamma)$, a validated therapeutic target in type 2 diabetes, which regulates the expression of many genes critical to insulin sensitivity (Wu et al., 1999) as well as components of $\mathrm{A} \beta$ metabolism and toxicity (Mandrekar-Colucci and Landreth, 2011; Mandrekar-Colucci et al., 2012). While many large-scale clinical trials for dementia due to $\mathrm{AD}$ failed to show efficacy of PPAR $\gamma$ agonism, evolving consensus considers their ineffectiveness likely to be due to testing in late-stage disease, a fate similar to many other $\mathrm{AD}$ drug candidates (Becker and Greig, 2013). In contrast, clinical trials performed with patients having mild cognitive impairment obtained positive outcomes using insulin sensitizers (Stockhorst et al., 2004; Watson et al., 2005; Risner et al., 2006; Sato et al., 2011). Thus, before overt neurodegeneration, insulin sensitizers may impinge upon signaling axes to modulate memory in early $\mathrm{AD}$ (Watson and Craft, 2004; Craft et al., 2012).

It is established that PPAR $\gamma$ agonism enhances cognition in AD animal models (Pedersen et al., 2006; Jiang et al., 2008; Landreth et al., 2008; Escribano et al., 2009; Rodriguez-Rivera et al., 2011), and that extracellular signal-regulated protein kinase (ERK) is essential for several forms of hippocampus-dependent learning and memory that are impaired in AD (Dineley et al., 2002, 2007; Hamann et al., 2002; Westerman et al., 2002; Sweatt, 2004; Hort et al., 2007; Hoefer et al., 2008). Our work using the 
PPAR $\gamma$ agonist rosiglitazone (RSG) to enhance cognition in the Tg2576 mouse model of AD demonstrated convergence between the hippocampal PPAR $\gamma$ and ERK signaling pathways (Denner et al., 2012). Since proper ERK2 activity is a requisite for hippocampus-dependent learning and memory in rodents (Atkins et al., 1998; Selcher et al., 2001), we speculated that PPAR $\gamma$ may serve to rein in dysregulated ERK2 to enhance hippocampal cognition. Here we show that RSG cognitive enhancement leads to increased recruitment of PPAR $\gamma$ to activated, phosphorylated ERK (pERK) in a multiprotein complex during memory consolidation for a hippocampus-dependent cognitive task. Acute inhibition of hippocampal PPAR $\gamma$, which blocks this type of memory consolidation, also prevented the increased recruitment of $\operatorname{PPAR} \gamma$ to pERK, suggesting that formation of this protein complex is requisite for memory formation. We also show that these complexes correlate with cognitive reserve in human $\mathrm{AD}$ and $\mathrm{AD}$ model animals. Further, we demonstrate the ability to reconstitute the PPAR $\gamma$-pERK association using in vitro recombinant protein pull-down assays, revealing that these two proteins have intrinsic properties for direct association.

\section{Materials and Methods}

Animals. Tg2576 mice were bred in the University of Texas Medical Branch at Galveston (UTMB) animal care facility by mating hemizygous Tg2576 (Hsiao et al., 1996) males with B6SJL/F1J females (stock\#100012, Jackson Laboratory). Mice were housed, $n \leq 5$ per cage, with food and water ad libitum. UTMB operates in compliance with the US Department of Agriculture Animal Welfare Act, the Guide for the Care and Use of Laboratory Animals, and Institutional Animal Care and Use Committee (IACUC)-approved protocols. Genotyping services were outsourced (Transnetyx), and genotypes were determined from tail clip biopsy specimens obtained at weaning; when mice were killed.

Rosiglitazone treatment. Eight-month-old male and female Tg2576 and WT littermates were fed a control diet or a $30 \mathrm{mg} / \mathrm{kg}$ RSG diet (Bio-Serv) for $30 \mathrm{~d}$, as previously described (Rodriguez-Rivera et al., 2011). Mouse food intake and body weights were monitored during the $30 \mathrm{~d}$ period, and no significant differences were observed by genotype or treatment group (data not shown). Additionally, RSG treatment did not confer any notable side effects, and age-related animal mortality rates were similar between groups. Animals were randomly assigned to receive control or RSG feed, and sample sizes were balanced by sex and genotype. Experimenters were blinded to treatment groups during key data acquisition and analysis steps.

Antibodies. Antibodies to pERK (1:1000; catalog \#9101), ERK (1:1000; catalog \#9102), MEK1/2 (dual-specificity mitogen-activated protein kinase kinase 1/2; 1:1000; catalog \#9122), RSK (1:1000; catalog \#9333), anti-rabbit HRP secondary (1:20,000; catalog \#7074), and anti-pERKconjugated Sepharose bead slurry (catalog \#3510) were from Cell Signaling Technology. Additional reagents included anti-PPAR $\gamma$ (1:500; catalog \#07-466, Millipore) and anti-PPAR $\gamma$-conjugated magnetic bead slurry (custom preparation, Affinity Life Sciences).

Fear conditioning. Behavioral experiments were performed during the lights-on phase (6:00 A.M. to 6:00 P.M.) in the UTMB Rodent In Vivo Assessment Core (directed by K.T.D.) within the UTMB Center for Addiction Research (directed by Dr. Kathryn Cunningham). Based upon power analyses of previous data, 10 (WT) to 20 (Tg2576) mice per group (male and female) were subjected to our standard two-pairing fear conditioning (FC) training protocol as previously described (Dineley et al., 2002; Taglialatela et al., 2009; Rodriguez-Rivera et al., 2011; Denner et al., 2012). No statistical differences in performance or response to drug treatment were measured between male and female mice; therefore, the sex groups were collapsed for data reporting. All experimental groups were balanced to include approximately equivalent numbers of each gender. Twenty-four hours after training, hippocampus-dependent contextual learning was assessed by quantifying freezing behavior when the animals were placed back into the training chamber. Freezing behavior was analyzed using automated software (FreezeFrame/View, Actimetrics) from digitally recorded videos (Actimetrics).

Contextual FC is amenable to the testing of manipulations hypothesized to disrupt memory consolidation (e.g., GW9662) as FC training is achieved in a single training session as opposed to those cognitive tasks that require repeated training sessions (e.g., Morris water maze; Westerman et al., 2002). We previously established that Tg2576 mice, either untreated or treated with RSG with or without GW9662, have intact perception as they exhibit similar shock threshold to WT animals, and also freeze comparably to WT animals in response to shock during training (Rodriguez-Rivera et al., 2011; Denner et al., 2012). In the present study, mice were not subjected to the hippocampus-independent cued memory test since our previous work has determined that Tg2576 mice do not exhibit a deficit in this task compared with WT mice, and PPAR $\gamma$ agonism does not affect the performance of either genotype (Dineley et al., 2002; Rodriguez-Rivera et al., 2011; Denner et al., 2012).

Under deep anesthesia [ $1 \mathrm{ml}$ of Avertin (Analytical 90710, Fluka) working solution ( $125 \mu \mathrm{l} ; 1.0 \mathrm{~g}$ of Avertin/ml tert-amyl-alcohol plus 9.88 $\mathrm{ml}$ of $0.9 \% \mathrm{NaCl})$ ], animals were killed by transcardial perfusion with ice-cold PBS containing protease and phosphatase inhibitors [P8340 protease inhibitor cocktail ( $30 \mathrm{~mm} \mathrm{NaF}, 10 \mathrm{~mm} \mathrm{Na}_{3} \mathrm{VO}_{4}, 1 \mathrm{~mm}$ PMSF, added fresh to perfusion buffer every $30 \mathrm{~min}$ ); Sigma-Aldrich]. This is in contrast to previous work wherein animals were killed via decapitation without perfusion (Rodriguez-Rivera et al., 2011). Whole brains were extracted, and hippocampi were dissected in ice-cold saline $(110 \mathrm{~mm}$ sucrose, $60 \mathrm{~mm} \mathrm{NaCl}, 3 \mathrm{~mm} \mathrm{KCl}, 1.25 \mathrm{~mm}$ sodium phosphate monobasic monohydrate, $28 \mathrm{~mm}$ sodium bicarbonate, $5 \mathrm{~mm}$ D-glucose, $1 \mathrm{~mm}$ L-ascorbic acid, $1 \mathrm{~mm} \mathrm{MgCl}_{2}, 1 \mathrm{~mm} \mathrm{CaCl}_{2}$ ). All samples were frozen on dry ice and stored at $-80^{\circ} \mathrm{C}$ until use.

Intracerebroventricular injection. The PPAR $\gamma$ antagonist GW9662 (Sigma-Aldrich) and vehicle ( $1 \%$ dimethylsulfoxide) were directly infused into the lateral ventricles using a modified free-hand method (Clark et al., 1968; Taglialatela et al., 2009; Denner et al., 2012). Using an aseptic technique, mice were anesthetized (isoflurane, 1-4\%) and the skull was exposed with a small incision along the midline to locate bregma (Paxinos et al., 1985). A 26 gauge needle was inserted $3 \mathrm{~mm}$ deep at $1 \mathrm{~mm}$ anterior and $1 \mathrm{~mm}$ lateral to bregma. GW9662 (32.5 pmol) or vehicle were delivered by an electronic programmable microinfuser (Harvard Apparatus) at $3 \mu \mathrm{l} / \mathrm{min}$ for $1 \mathrm{~min}$. Doses and delivery rates were determined based on previous work using GW9662 to antagonize PPAR $\gamma$ function in the CNS (Bjorklund et al., 2012; Denner et al., 2012). Following infusion, the needle was stabilized for 1 min to ensure complete delivery and prevent reflux. No mice exhibited evidence of misplaced injections or brain hemorrhage. Following suturing, pain and local inflammation were attenuated via application of a topical NSAID (Neosporin) containing neomycin, bacitracin, and Polymyxin B antibiotics according to the IACUC-approved protocol. Intracerebroventricular injections were administered $4 \mathrm{~h}$ before FC training, and $8 \mathrm{~h}$ before killing of the animal and tissue harvest. This time point was chosen based on our previous work demonstrating that the GW9662 peak effect on PPAR $\gamma$ was $8 \mathrm{~h}$ postinjection (Denner et al., 2012), which also corresponds to the timeframe for hippocampal ERK-mediated memory consolidation (McGaugh, 2000; Trifilieff et al., 2007).

Protein extraction. Nuclear extracts were isolated from hippocampi at $4^{\circ} \mathrm{C}$ using the Active Motif Nuclear Extract Kit (catalog \#40010) then stored at $-80^{\circ} \mathrm{C}$. The resultant extracts were composed of nuclei (nuclear) and a separate fraction composed of the remaining cellular components (non-nuclear). Total protein concentrations in extracts were determined using a BCA protein assay kit (catalog \#23225, Thermo Scientific).

Quantitative immunoprecipitation. Hippocampal extracts were thawed on ice, and $200 \mu \mathrm{g}$ (nuclear) or $500 \mu \mathrm{g}$ (non-nuclear) of protein was suspended in $500 \mu \mathrm{l}$ of extract buffer ( $25 \mathrm{~mm}$ HEPES, $0.1 \%$ Triton X-100, $10 \%$ glycerol), supplemented with $0.02 \mathrm{M}$ Sigma protease inhibitor cocktail (P8340), $0.02 \mathrm{M} \mathrm{NaF}$, and $0.02 \mathrm{M} \mathrm{Na}_{3} \mathrm{VO}_{4}$. Ten microliters of antipERK-conjugated Sepharose bead slurry (catalog \#3510, Cell Signaling Technology) or $10 \mu \mathrm{l}$ of anti-PPAR $\gamma$-conjugated magnetic bead slurry (Affinity Life Sciences) was added, and this mixture was allowed to incubate in a rotating shaker at $4^{\circ} \mathrm{C}$ for $\sim 18 \mathrm{~h}$. All remaining steps were 
Table 1. Demographic and cognitive data for control and AD subject cortical samples

\begin{tabular}{|c|c|c|c|c|c|c|c|c|}
\hline Case no. & Diagnosis & $\begin{array}{l}\text { Age at } \\
\text { onset } \\
\text { (years) }\end{array}$ & $\begin{array}{l}\text { Age } \\
\text { (years) }\end{array}$ & Sex & PMI & $\begin{array}{l}\text { Braak } \\
\text { stage }\end{array}$ & $\begin{array}{l}\text { Plaque } \\
\text { stage }\end{array}$ & MMSE \\
\hline 1008 & Control & & 77.4 & $\mathrm{~F}$ & 12 & 0 & 4 & $>25$ \\
\hline 1525 & Control & & 88.7 & $\mathrm{~F}$ & 3 & 1 & 4 & 29 \\
\hline 1029 & Control & & 73 & $\mathrm{~F}$ & 4 & 0 & 4 & $>25$ \\
\hline 767 & Control & & 86 & $\mathrm{~F}$ & 8 & 2 & 4 & $>25$ \\
\hline 1775 & Control & & 85 & M & 38.5 & 3 & 3 & 28 \\
\hline 1013 & Control & & $>89$ & $M$ & 6 & 1 & 0 & 29 \\
\hline 1052 & Control & & 87.7 & $M$ & 8 & 2 & 1 & 29 \\
\hline 1766 & $A D$ & 57.3 & 63 & $\mathrm{~F}$ & 3.5 & 6 & 1 & 18 \\
\hline 1770 & $A D$ & 70.2 & 82 & $\mathrm{~F}$ & 6.5 & 6 & 1 & 15 \\
\hline 1811 & $A D$ & 87.3 & $>89$ & $M$ & 18 & 6 & 2 & 21 \\
\hline 1774 & $A D$ & & $>89$ & $M$ & 3.25 & 6 & 1 & 2 \\
\hline 1742 & $A D$ & 48.6 & 64 & $M$ & 9.25 & 6 & 1 & 1 \\
\hline 1777 & $A D$ & & 67 & $\mathrm{~F}$ & 20.5 & 6 & 3 & 9 \\
\hline 1827 & $A D$ & & $>89$ & $\mathrm{~F}$ & 5 & 6 & 2 & 16 \\
\hline
\end{tabular}

F, Female; M, male; PMI, post-mortem interval.

performed at $4^{\circ} \mathrm{C}$, unless otherwise noted. Following incubation, Sepharose bead samples were pelleted by centrifugation $(14,000 \times g$ for $1 \mathrm{~min})$ or magnetic samples were isolated using a magnetic stand; in each case, the supernatant was then removed. The pelleted beads were washed by resuspension in extract buffer for $20 \mathrm{~min}$ then centrifuged $(14,000 \times g$ for $1 \mathrm{~min}$ ) or placed in the magnetic stand to isolate washed beads. Bead wash was repeated four times. Protein was eluted in $30 \mu \mathrm{l}$ of $2 \times \mathrm{Laemmli}$ sample buffer (20\% SDS, $20 \%$ glycerol, $1 \mathrm{~m}$ Tris, $5 \% \beta$-mercaptoethanol, $8 \mathrm{M}$ urea, double-distilled $\mathrm{H}_{2} \mathrm{O}$, bromophenol blue) and incubated for 5 min at $95-100^{\circ} \mathrm{C}$. One final bead pelleting step was performed to avoid loading beads onto SDS-PAGE gels.

Quantitative immunoblot following immunoprecipitation. Extracted proteins were resolved by SDS-PAGE (Bio-Rad, 7.5\% Mini-PROTEAN TGX) and electroblotted onto nitrocellulose. To quantitatively compare between immunoblot film bands, a crude whole-brain lysate $(20 \mu \mathrm{g} /$ well) prepared from a homogenate of $\sim 40 \mathrm{C} 57 \mathrm{BL} / 6 \mathrm{~J}$ brains was included in triplicate on each gel as an internal standard (further described below).

Following electrophoresis and transfer, each membrane was blocked (2\% Advanced ECL blocking solution, GE Healthcare), and incubated with primary and secondary antibodies. Samples were visualized via chemiluminescence using the GE Healthcare ECL Western blotting reagent system, according to the manufacturer's instructions. Exposure to GE Healthcare Hyperfilm ECL was performed to obtain band intensities within the linear range of the antibody combinations used.

Immunoblot membranes were scanned at $300 \mathrm{dpi}$, and numeric band density and background values were acquired using ImageJ software [National Institutes of Health (NIH)]. The numeric values for the loading control (LC) protein from each of the three identical C57BL/6J internal standards was averaged (LC), and all other samples (e.g., PPAR $\gamma$ or pERK2 from the immunoprecipitation) were normalized to the LC average. The PPAR $\gamma$ value in our control sample was chosen as a normalization value to remain in the linear range of the samples we were investigating. Because immunoprecipitates (IPs) were loaded with 200 or $500 \mu \mathrm{g}$ of protein, a standard loading control such as actin would have generated a signal too intense to accurately quantify the PPAR $\gamma$ and pERK that is present. Thus, this method allows for more precise quantitative comparison between different gels and across different experiments. After normalizing PPAR $\gamma$ and pERK2 protein density values for each sample, the amount of PPAR $\gamma$ that co-immunoprecipitated with pERK was determined by taking the ratio of normalized PPAR $\gamma$ and normalized pERK2. This step corrected for any variation in immunoprecipitation efficiency. Thus, the final value represents the relative amount of PPAR $\gamma$ that is associated with pERK2 in a given sample normalized to a low-abundance protein whose expression level is not subject to the effects of the pharmacological manipulations used. Our quantification and normalization procedure was calculated as follows:
A IP: $p$ ERK IB: $p E R K$

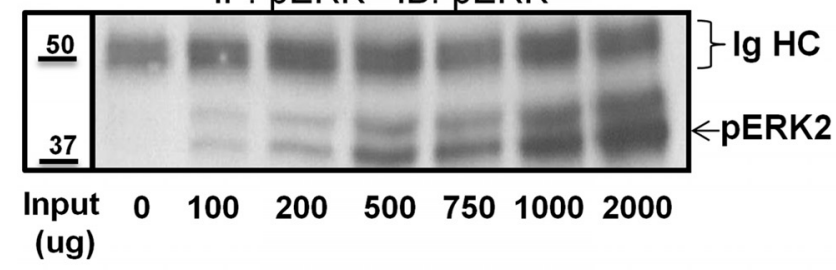

B IP: pERK IB: PPARY
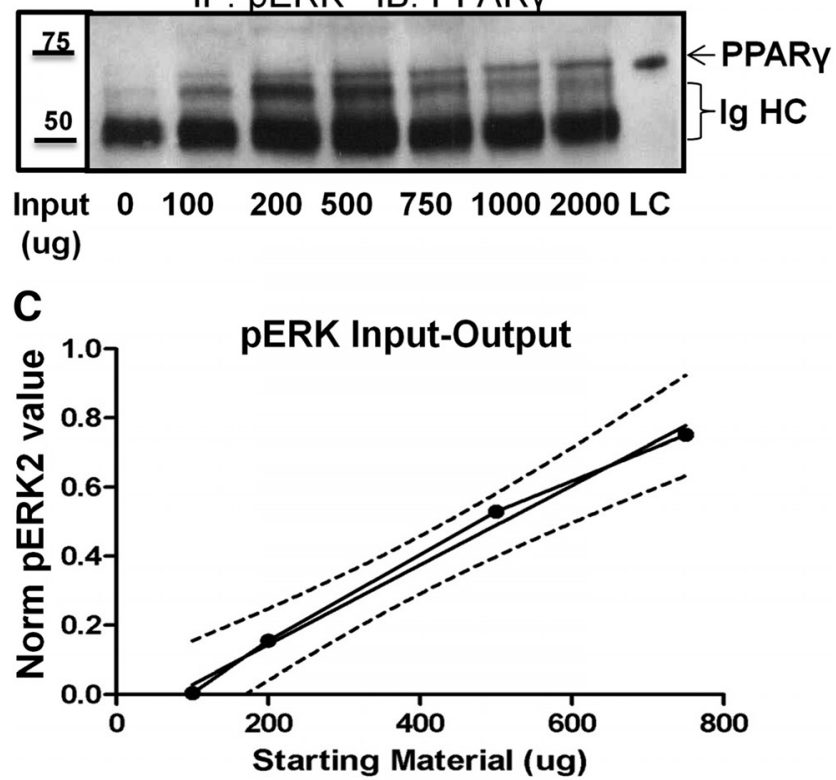

Figure 1. PPAR $\gamma$ associates with $p E R K$ in vivo in Tg2576 hippocampal multiprotein complexes. $\boldsymbol{A}, \boldsymbol{B}$, Western immunoblots (IBs) for pERK and PPAR $\gamma$ in pERK IPs from Tg2576 using anti-pERK-conjugated Sepharose beads with increasing input of hippocampal nuclear extract. C, Input- output IP linear relationship for pERK IPs ( $r^{2}=0.991$ up to $750 \mu \mathrm{g}$ of input). Densitized Western blot values were normalized to the loading control described in Materials and Methods and Fig. $2 A$. Dotted lines represent the $95 \%$ confidence intervals. IgHC, Ig heavy chain.

\section{$\frac{\left\{\left(\text { PPAR } \gamma_{\text {RawValue }}\right) /[\operatorname{Avg}(\mathrm{LC} 1+\mathrm{LC} 2+\mathrm{LC} 3)]\right\}}{\left\{\left(\mathrm{pERK} 42_{\text {RawVal }}\right) /[\operatorname{Avg}(\mathrm{LC} 1+\mathrm{LC} 2+\mathrm{LC} 3)]\right\}}=\frac{\text { Normalized }}{\operatorname{PPAR} \gamma / \mathrm{pERK}}$}

An example of this procedure can be found in Figure 2A. Quadruplicate runs on six individual animals using this approach yielded a coefficient of variation between $1 \%$ and $4.8 \%$ for the four PPAR $\gamma /$ pERK ratios calculated, thus demonstrating the reproducibility and accuracy of immunoprecipitation (see Fig. $2 B$ ).

Recombinant protein and in vitro GST pull-down assay. In vitro recombinant protein association studies were performed using Pierce glutathione agarose beads (catalog \#16100, Thermo Scientific), recombinant human PPAR (catalog \#RCP9207, Randox Life Sciences), GST-tagged (N-terminal) recombinant human active ERK2 (catalog \#1230-KS, R\&D Systems), and GST-tagged (N-terminal) recombinant human ERK2 (catalog \#10030-H09B, Sino Biological). All steps were performed at $4^{\circ} \mathrm{C}$, unless otherwise specified. Glutathione beads were suspended in $250 \mu \mathrm{l}$ $1 \times$ TBS $(0.02 \mathrm{M}$ Tris, $0.14 \mathrm{M} \mathrm{NaCl})$ and incubated with $100 \mathrm{ng}$ of recombinant PPAR $\gamma$ and $100 \mathrm{ng}$ of either recombinant GST-pERK or GST-ERK protein on a rocker overnight. Controls were prepared to include all possible combinations of glutathione beads and recombinant proteins (see Fig. 5). Beads were pelleted by centrifugation $(700 \times g$ for $2 \mathrm{~min})$, and the supernatant was removed. Samples were washed $(4 \times 1 \mathrm{~min})$ in $1 \times \mathrm{TBS}$, followed by centrifugation $(700 \times g$ for $2 \mathrm{~min})$ to pellet beads. Bound proteins were eluted with $2 \times$ sample buffer (30\% glycerol, $2 \%$ SDS, 62.5 mm Tris, pH 6.8, bromophenol blue) and heated for $5 \mathrm{~min}$ at $95-100^{\circ} \mathrm{C}$.

Human brain tissue. Frozen human cortex was acquired from the Oregon Brain Bank at Oregon Health and Science University (OHSU) in Portland, OR, as previously described (Bjorklund et al., 2012). Briefly, all 

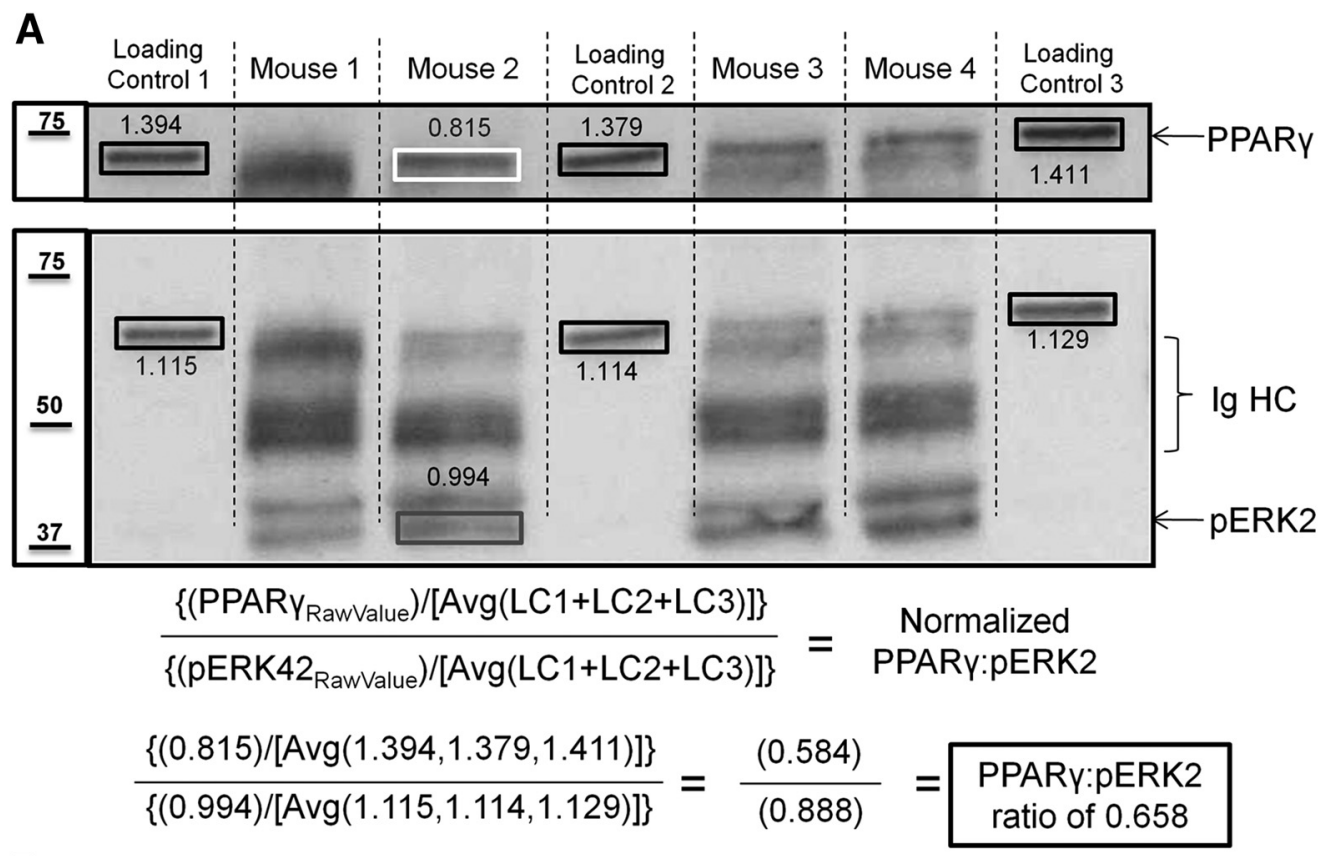

B

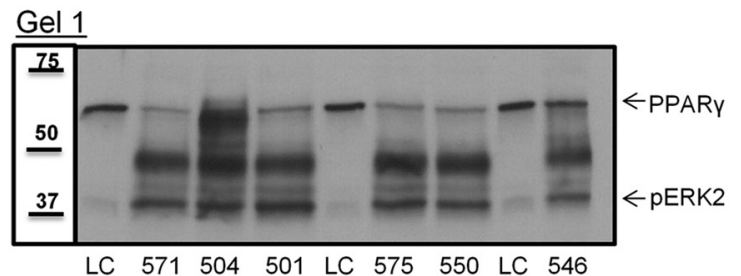

Gel 2

LC 571504501 LC 575550 LC 546
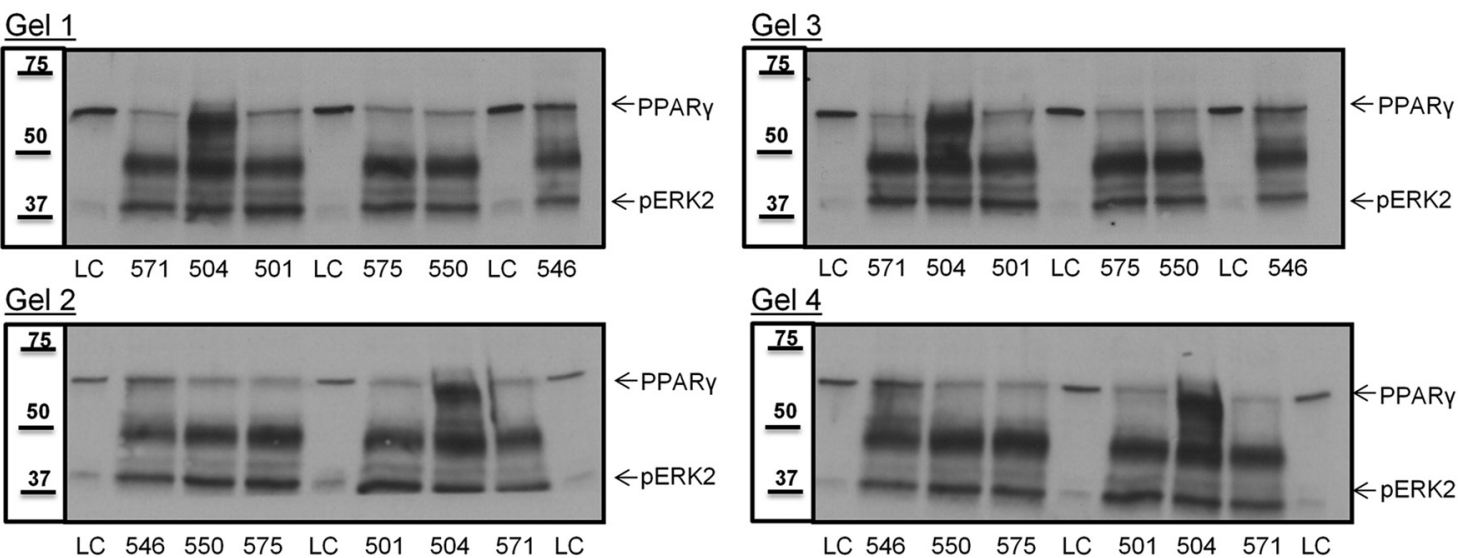

Gel 4

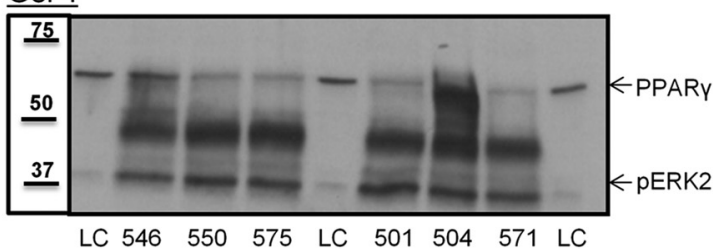

\begin{tabular}{|c|c|c|c|c|c|c|}
\hline Animal ID & 571 & 504 & 501 & 575 & 550 & 546 \\
\hline Coefficient of variation & $3.12 \%$ & $1.46 \%$ & $4.77 \%$ & $4.49 \%$ & $3.33 \%$ & $1.24 \%$ \\
\hline
\end{tabular}

Figure 2. Quantification method to determine PPAR $\gamma / \mathrm{pERK} 2$ ratios. $A$, Shown is an example Western blot for PPAR $\gamma$ and $p E R K$ in $p E R K$ IPs from four individual mice. For quantification across multiple immunoblots of IP material, a homogenate prepared from pooled brains from C57BL/6J mice was used as a LC and was resolved in triplicate (lanes 1, 4, and 7) on each SDS-PAGE gel. pERK IPs from four individual mice (lanes 2, 3,5, and 6) are depicted. For the data described herein, immunoblots for PPAR $\gamma$ or pERK2 from the IPs were normalized relative to the LC. PPAR $\gamma$ in the LC lanes was chosen as the normalization protein because it tracked in the linear range with immunoprecipitated PPAR $\gamma$ and pERK2 for their respective exposures. After acquiring normalized values for immunoprecipitated PPAR $\gamma$ and pERK2 proteins for each individual animal's hippocampal extract, the amount of PPAR $\gamma$ that coimmunoprecipitates with pERK was calculated by taking the ratio of normalized PPAR $\gamma$ to normalized pERK2. In the example above, Mouse 2 has a hippocampal PPAR $\gamma /$ pERK2 ratio of 0.658 . B, PPAR $\gamma /$ pERK2 ratios are highly reproducible. Western blots of PPAR $\gamma$ and $p E R K$ in four independent pERKIPs from six individual animals (lanes 2, 3, 4,6,7, and 8 ) and the triplicate LC (lanes 1,5,9) resolved by four separate gels. The PPAR $\gamma / \mathrm{pERK} 2$ ratios were calculated as in Figure $2 A$, and the coefficient of variation for each individual animal was determined. All replicate IPs yielded a coefficient of variation of $\leq 4.8 \%$.

donor subjects were enrolled and evaluated in studies at the NIHsponsored C. Rex and Ruth H. Layton Aging Alzheimer's Disease Center at OHSU. Subjects were evaluated for neurological and neuropsychological competency annually and subsequently assigned a clinical dementia rating (CDR) by an experienced clinician. $\mathrm{AD}$ subjects were diagnosed by a clinical team consensus conference, met National Institute for Neurological and Communicative Disorders and Stroke-Alzheimer's Disease and Related Disorder Association diagnostic criteria for clinical AD, had a CDR > 1.0 , and had AD status confirmed at autopsy following informed consent. All tissue was examined by a neuropathologist to confirm neurodegenerative pathology including neurofibrillary tangles and neuritic plaques. Amyloid score was assessed using standardized Consortium to Establish a Registry for Alzheimer's Disease criteria ( 0 , no plaques; 1 , sparse plaques; 2 , moderate plaques; 3 , dense plaques), and a Braak stage ( $0-6$ with 6 being the most severe) indicative of the level and location of hyperphosphorylated tau tangles. In addition to the pathological information detailed above, demographic data including age, sex, and Mini Mental State Examination (MMSE) score were received along with the frozen tissue, and details can be found in Table 1. Power analysis on these data, which were subjected to correlation analyses, found that seven Alzheimer's disease samples provided $>95 \%$ confidence that a type I error did not occur.

Statistics. Data are reported as the mean \pm SEM. Statistical analyses were conducted using GraphPad Prism 6. Where indicated, a one-way or two-way ANOVA was performed for group analyses followed by either Tukey or Bonferroni post hoc comparison. Correlations were determined by Pearson correlation test for linearity, and coefficient of variation was assessed by calculating the average percentage deviation from the respective group mean. 


\section{Results}

While previous reports have described many binding partners for PPAR $\gamma$ (Miyamoto-Sato et al., 2010) and pERK (Yoon and Seger, 2006; von Kriegsheim et al., 2009), our observations regarding convergence of these signaling axes during cognitive enhancement with RSG (Denner et al., 2012) led us to test whether PPAR $\gamma$ and pERK (pERK2) were associated with each other in multiprotein complexes. We found that pERK multiprotein complexes immunoprecipitated from Tg2576 hippocampal extracts (Fig. 1A) also contained PPAR $\gamma$ (Fig. $1 B$ ). We established that the pERK immunoprecipitation exhibited a linear input-output relationship up to $750 \mu \mathrm{g}$ of input protein $\left(r^{2}=0.991\right.$; Fig. $\left.1 C\right)$. In reciprocal studies, PPAR $\gamma$ IPs contained pERK and the PPAR $\gamma$ IPs exhibited linearity up to 500 $\mu$ g of input ( $r^{2}=0.849$, data not shown). Given the narrower confidence intervals with the pERK IPs, we developed a quantitative method to assess the PPAR $\gamma /$ pERK ratio in pERK IPs using $200 \mu \mathrm{g}$ of hippocampal protein (Fig. $2 A$ ), thereby ensuring that our IPs were within the linear range and exhibited high reproducibility (individual animal coefficients of variation $<4.8 \%$; Fig. $2 B$ ).

We next examined the PPAR $\gamma /$ pERK ratio in postmortem human brain samples from $\mathrm{AD}$ and age-matched control subjects and found a significant correlation between nuclear PPAR $\gamma / \mathrm{pERK}$ ratio in AD brain and MMSE, a measure of cognitive reserve (Fig. $3 A, B$ ). No correlation was found between MMSE score and the PPAR $\gamma /$ pERK ratio in the aged-matched control group. In agreement, we observed similar relationships in mouse hippocampus where the PPAR $\gamma /$ pERK ratio correlated with cognitive performance in Tg2576 mice but not in WT mice (Fig. 3C). Since RSG treatment alleviated Tg2576 cognitive deficits and the amount of hippocampal nuclear PPAR $\gamma$ in complex with pERK correlated with better hippocampus-dependent cognitive performance, we tested whether RSG treatment simply led to an increase in the steady-state PPAR $\gamma / \mathrm{pERK}$ ratio and found that it was not affected by RSG treatment in either WT or Tg2576 mice (Fig. 3D), leading to the conclusion that the cognitive enhancing effects of $\operatorname{PPAR} \gamma$ agonism were not due to increased constitutive formation of PPAR $\gamma$-pERK complexes. These observations provide the first evidence for a physical interaction between PPAR $\gamma$ and pERK, and provide a molecular mechanism for the convergence of these two pathways in RSG-mediated cognitive enhancement in the Tg2576 mouse model for AD.

Since (1) RSG treatment enhances hippocampus-dependent cognition in both $\mathrm{AD}$ animal models and some humans with $\mathrm{AD}$ (Watson and Craft, 2004; Pedersen et al., 2006; Jiang et al., 2008; Landreth et al., 2008; Escribano et al., 2009; Rodriguez-Rivera et al., 2011), (2) ERK phosphorylation-dependent activation is necessary for hippocampal memory consolidation (Atkins et al., 1998; Sweatt, 2004), and (3) PPAR $\gamma$ associates with pERK in protein complexes, we analyzed the dynamics of these complexes
B
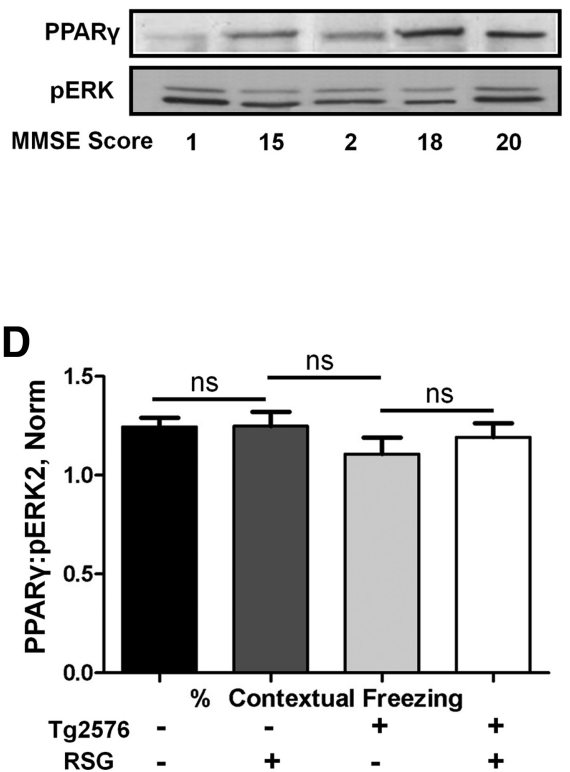

Figure 3. PPAR $\gamma /$ pERK2 ratios in human AD brains and Tg2576 mouse hippocampi correlate with cognitive performance. $A$, between genotype or treatment on PPAR $\gamma /$ pERK2 ratios. Two-way ANOVA, $n=7-12 /$ group, $p=0.565, F_{(1,34)}=0.3375$. Densitometric analysis of the Western blots are presented as the mean \pm SEM. ns, Nonsignificant.

during memory consolidation. RSG-treated and RSG untreated 9-month-old Tg2576 and WT littermates were subjected to twopair FC training, wherein acquisition of the task was unaffected (Rodriguez-Rivera et al., 2011), and then were killed $4 \mathrm{~h}$ later (Fig. $4 A$ ) at a time point that correlated with the peak effect of PPAR $\gamma$ agonism on FC consolidation (Denner et al., 2012). Animals that were not exposed to the training chamber context served as controls. RSG-treated Tg2576 mice subjected to FC training exhibited significantly increased PPAR $\gamma /$ pERK ratios in both the nuclear (Fig. 4B) and non-nuclear fractions (Fig. 4C) compared with untreated Tg2576 mice. Two-way ANOVA revealed a significant interaction between RSG treatment and training in regard to the Tg2576 PPAR $\gamma / \mathrm{pERK}$ ratio, demonstrating that PPAR $\gamma$ agonism facilitated PPAR $\gamma$ recruitment to pERK during Tg2576 memory consolidation.

To establish the specificity of RSG induction of PPAR $\gamma$ recruitment to pERK during memory consolidation, we performed intracerebroventricular injection of the PPAR $\gamma$ antagonist GW9662 $4 \mathrm{~h}$ before FC training, an intervention that does not affect acquisition but blocks RSG-mediated cognitive enhancement (Denner et al., 2012) and is much more rapid than genetic intervention (Ryan et al., 2011). In a complementary manner, PPAR $\gamma$ antagonism blocked training-induced increased recruitment of PPAR $\gamma$ to pERK in the nuclear fraction (Fig. 4D), with a similar trend in the non-nuclear fraction (Fig. $4 E$ ). In agreement with previous reports that PPAR $\gamma$ agonism does not affect WT cognitive performance (Denner et al., 2012), the nuclear (Fig. 4F) and non-nuclear (Fig. 4G) hippocampal PPAR $\gamma /$ pERK2 ratios were unaffected by RSG treatment or GW9662 during WT memory consolidation. Two-way ANOVA and post hoc analysis revealed 
A

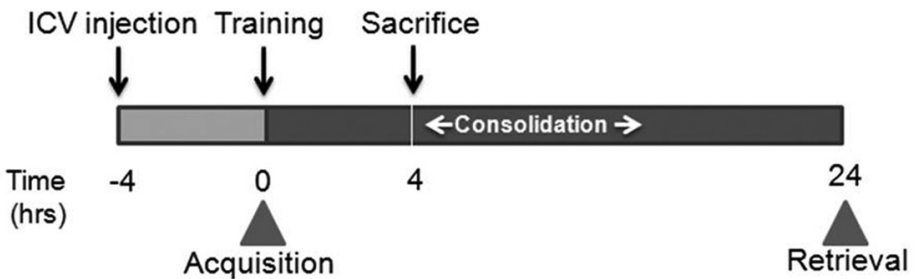

B

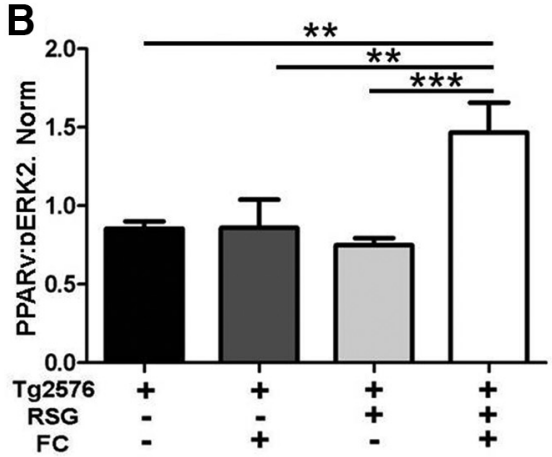

D

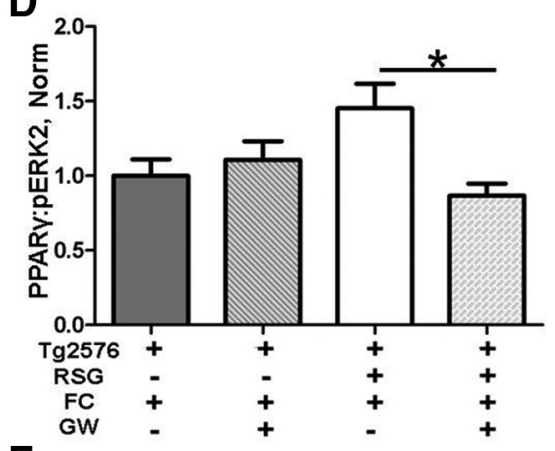

$\mathbf{F}$

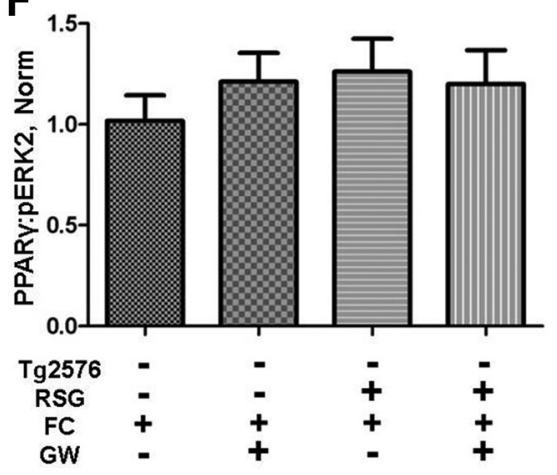

H

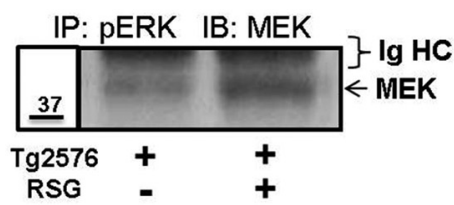

C

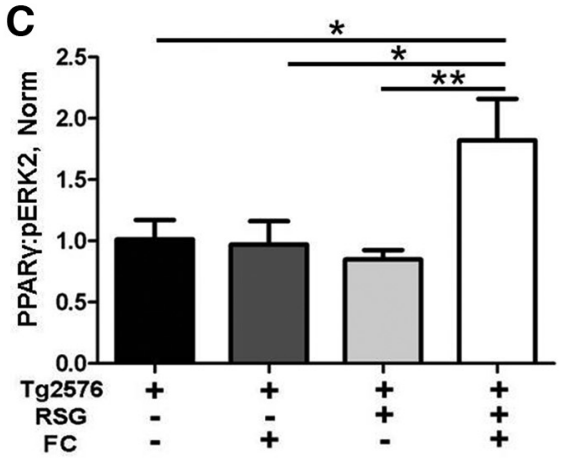

$\mathrm{E}$

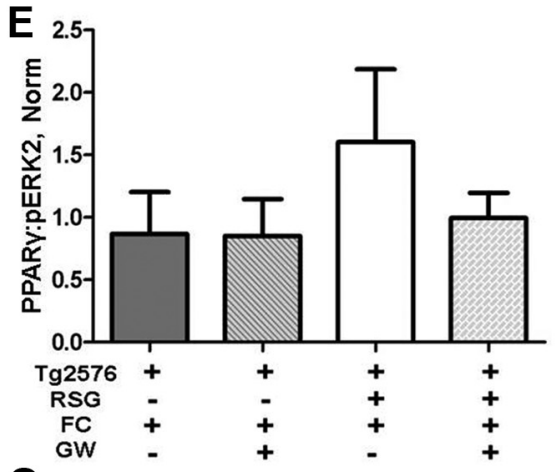

$\mathbf{G}$

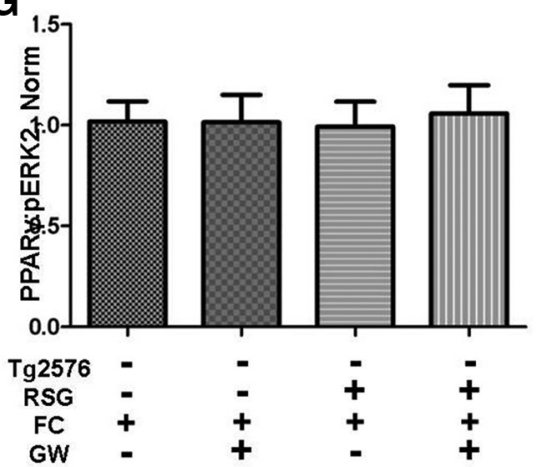

I

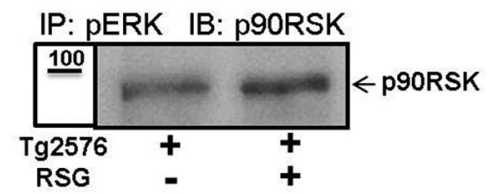

Figure 4. PPAR $\gamma$ agonism increases the recruitment of PPAR $\gamma$ to $\mathrm{PERK}$ during memory consolidation in $\operatorname{Tg} 2576$ mice. $\boldsymbol{A}$, Experimental paradigm: $\operatorname{Tg} 2576$ mice fed control $(-)$ or RSG $(+)$ diet were either naive $(F C-)$ or trained in the $F C$ task $(F C+)$, then were killed $4 \mathrm{~h}$ post-training during consolidation to determine hippocampal PPAR $\gamma / \mathrm{pERK} 2$ ratios. For PPAR $\gamma$ antagonism studies, $4 \mathrm{~h}$ before training vehicle $(\mathrm{GW}-)$ or $\mathrm{GW} 9662(\mathrm{GW}+)$ were intracerebroventricularly administered, and ratios were determined $4 \mathrm{~h}$ after training. $\boldsymbol{B}, \boldsymbol{C}$, Effects of RSG and fear conditioning on nuclear ratios (two-way ANOVA, $n=7-8 /$ group, $F_{(1,26)}=11.28, p=0.002,0.025,0.002$ for interaction, treatment, and training, respectively; $\boldsymbol{B}$ ) and non-nuclear ratios (two-way ANOVA, $n=7 /$ group, $F_{(1,24)}=8.155, p=0.009,0.064,0.015$ for interaction, treatment, and training, respectively; $\left.\boldsymbol{C}\right) . \boldsymbol{D}, \boldsymbol{E}$, Effects of PPAR $\gamma$ antagonism on nuclear ratios (two-way ANOVA, $F_{(1,40)}=5.705, p=0.022,0.121,0.559$ for interaction, treatment, and intracerebroventricular injection, respectively; $\boldsymbol{D}$ ) and non-nuclear ratios (two-way ANOVA, ns, $F_{(1,31)}=1.016 ; \boldsymbol{E}$ ). $\boldsymbol{F}, \mathbf{G}$, Neither RSG treatment nor GW9662 antagonism had any effect on WT PPAR/pERK2 ratios in nuclear (two-way ANOVA, $p=$ $0.41, \mathrm{~ns}, F_{(1,37)}=0.694 ; \boldsymbol{F}$ ) or non-nuclear (two-way ANOVA, $p=0.78, \mathrm{~ns}, F_{(1,24)}=0.074 ; \boldsymbol{G}$ ) fractions. $\boldsymbol{H}, \boldsymbol{I}, \mathrm{pERK}$ association MEK $(n=5 /$ group, representative blot; $\boldsymbol{H})$ or p90RSK $(n=2 /$ group; $\boldsymbol{I}) .{ }^{*} p<0.05 ;{ }^{* *} p \leq 0.01$.

an interaction between RSG treatment and GW9662 intracerebroventricular injection on Tg2576 PPAR $\gamma /$ pERK ratios, indicating that RSG and GW9662 had significant effects on the complexes. Together, these results suggest that PPAR $\gamma$ agonism with RSG facilitates the association of hippocampal PPAR $\gamma$ with pERK to restore proper memory consolidation in the Tg2576 mouse model of AD.

We next investigated whether RSG treatment had an effect on other members of the ERK cascade. An essential mediator of ERK activation is phosphorylation by the upstream binding partner and kinase MEK1/2 (Canagarajah et al., 1997), which is essential for FC (Shalin et al., 2004). Indeed, we found MEK associated with pERK, an effect enhanced by RSG (Fig. $4 H)$. We next tested for pERK binding to ribosomal S6 kinase protein $1 \alpha$, MAPKactivated protein kinase-1a (p90RSK), a downstream pERK binding partner and effector kinase (Gavin and Nebreda, 1999; Smith et al., 1999) that is also required for memory consolidation (Morice et al., 2013). RSK was associated with pERK, again increased in response to RSG agonism of PPAR $\gamma$ (Fig. 4I).

To further understand the interaction between PPAR $\gamma$ and pERK, we next tested whether these proteins had the intrinsic ability to directly associate in the absence of other proteins. We used recombinant GST-tagged pERK (GST-pERK2) and PPAR $\gamma$ proteins in an in vitro glutathione bead pull-down assay in an attempt to reconstitute the in vivo interaction detected by hippocampal co-immunoprecipitation. We found that increasing amounts of input PPAR $\gamma$ resulted in increased GSTpERK pulldown of PPAR $\gamma$ (Fig. 5A) in a linear response (Fig. 5B). Control reactions demonstrated that PPAR $\gamma$ only associated with the beads in the presence of pERK, suggesting that the observed $\operatorname{PPAR} \gamma$ signal was due to a direct association between the two proteins. When similar binding studies were performed with PPAR $\gamma$ and GST-tagged nonphosphorylated ERK2, no association with PPAR $\gamma$ was detected (Fig. 5C). Thus, ERK activation/phosphorylation is necessary for PPAR $\gamma$ binding, providing an intriguing level of specificity to these complexes.

\section{Discussion}

Identification of the molecular mechanisms that contribute to memory impairment in $\mathrm{AD}$ elucidate therapeutic strategies for the everexpanding population of humans in whom the disease was diagnosed (Thies 
and Bleiler, 2013). In the past several years, many studies have shown that agonists of PPAR $\gamma$ enhance memory in some patients (Watson et al., 2005; Risner et al., 2006; Sato et al., 2011) and in genetic AD mouse models in tasks that require intact ERK MAPK signaling (e.g., associative learning in the contextual FC paradigm and spatial navigation in the Morris water maze; Pedersen et al., 2006; Jiang et al., 2008; Landreth et al., 2008; Escribano et al., 2009; Rodriguez-Rivera et al., 2011). Still, the therapeutic mechanism by which PPAR $\gamma$ agonism led to improved cognition remains poorly understood.

It is well established that consolidation after a learning event is an essential phase in the formation of new memories, a process that requires dynamic phosphorylationdependent activation of hippocampal ERK (Atkins et al., 1998; Sweatt, 2004; Trifilieff et al., 2007). Prior studies in our laboratory demonstrated that PPAR $\gamma$-mediated cognitive enhancement linked the hippocampal PPAR $\gamma$ and ERK MAPK signaling pathways by promoting the transcription of peroxisome proliferator response element-containing $\operatorname{PPAR} \gamma$ target genes and Cre-containing ERK-regulated target genes (Denner et al., 2012). Given that ERK/CREB/CBP/Cre-dependent signaling is requisite for hippocampal memory consolidation (Atkins et al., 1998; McGaugh, 2000; Vecsey et al., 2007), the current study investigated whether PPAR $\gamma$ agonism can directly modulate ERK to enhance this process.

Here we found that PPAR $\gamma$ agonism induced recruitment of PPAR $\gamma$ to pERK during memory consolidation, and that these complexes correlated with cognitive reserve in humans with $\mathrm{AD}$ and in a genetic AD mouse model. The fact that hip-

pocampal PPAR $\gamma$ association with pERK during memory consolidation increased only in RSG-treated Tg2576 mice implies that PPAR $\gamma$-mediated effects on ERK happen selectively during $\mathrm{AD}$-related hippocampal dysfunction. In this regard, we observed that acute pharmacological antagonism of PPAR $\gamma$ with GW9662 only blocked hippocampal memory consolidation in RSG-treated Tg2576 (Denner et al., 2012) via prevention of hippocampal PPAR $\gamma$ association with pERK during this process. Thus, we conclude that hippocampal PPAR $\gamma$ activity is necessary to enhance the formation of complexes during memory consolidation. Direct binding of recombinant PPAR $\gamma$ and pERK in vitro suggests an intrinsic affinity that may underlie the cognitive enhancing activity of RSG.

Cognitive reserve in $\mathrm{AD}$ is a measure of the ability of the brain to resist damage inflicted by AD pathology (Sperling et al., 2011). The observation that 9-month-old Tg2576 mice on average perform poorly in the hippocampus-dependent contextual FC task, while individual animals vary considerably, led us to hypothesize that if the PPAR $\gamma /$ pERK ratio was relevant to cognitive performance, individual human or animal ratios would correlate with
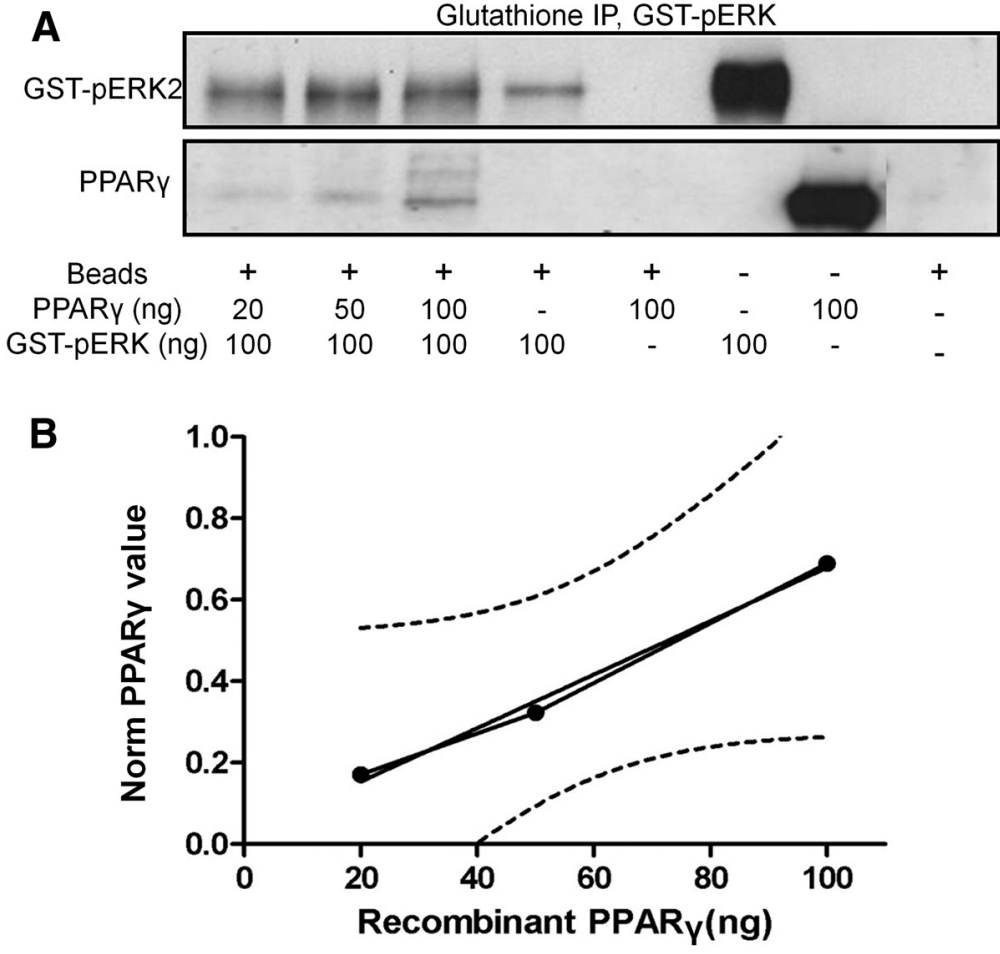

C Glutathione IP, GST-ERK

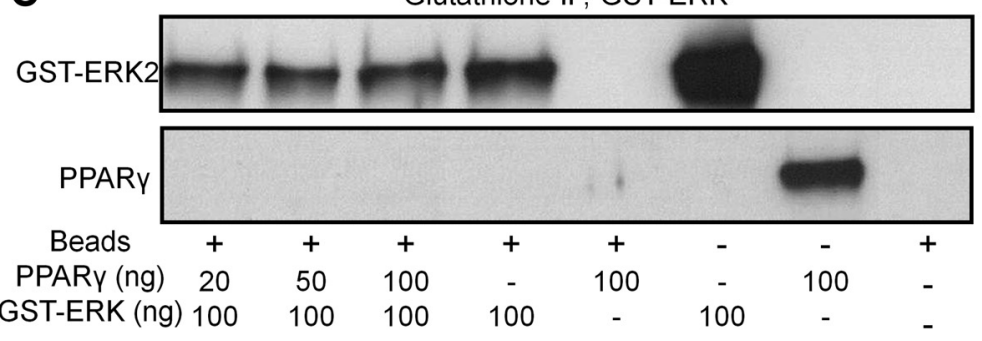

Figure 5. PPAR $\gamma$ and pERK recombinant proteins associate in vitro. $\boldsymbol{A}$, Western blot for pERK (top) and PPAR $\gamma$ (bottom) following incubation of recombinant human GST-pERK2 with increasing amounts of human PPAR $\gamma$ followed by glutathione bead intervals. C, Western blot for nonphosphorylated ERK (top) and PPAR $\gamma$ (bottom) following incubation of recombinant GSTnonphosphorylated ERK2 with increasing amounts of human PPAR $\gamma$ followed by glutathione bead affinity isolation.

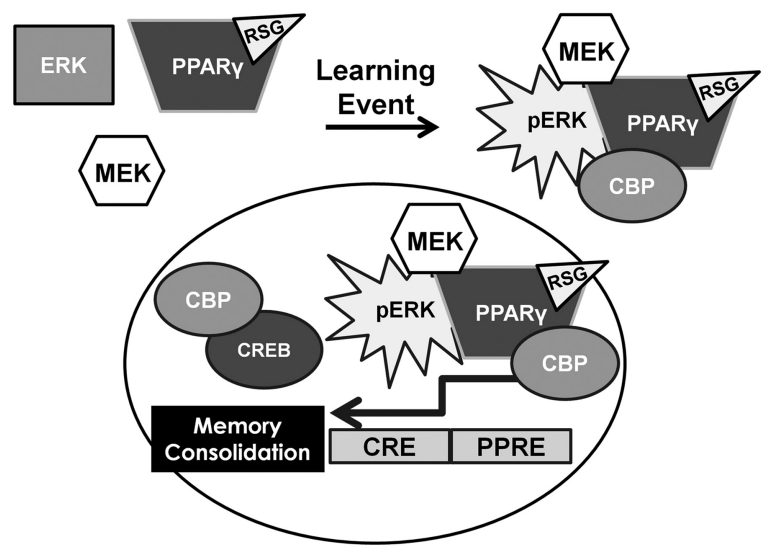

Figure 6. Working model for PPAR $\gamma$-mediated enhancement of memory consolidation in AD. In the cognitively impaired Tg2576 AD model mice, ligand-bound PPAR $\gamma$ is recruited to activated ERK following a learning event. The complex recruits a number of other transcriptional regulatory proteins, ultimately increasing ERK downstream efficiency, including Cre-mediated gene transcription, as well as activation of p90RSK and Elk-1. 
their respective performance. Indeed, we found in humans with $\mathrm{AD}$ that cognitive performance, assessed by the MMSE score, positively correlated with the PPAR $\gamma / \mathrm{pERK}$ ratio. In further support of this hypothesis, we found that $\mathrm{Tg} 2576$ mice contextual freezing behavior, a reflection of cognitive performance, also positively correlated with the PPAR $\gamma /$ pERK ratio. Notably, neither age-matched human control subjects nor WT littermates of Tg2576 mice exhibited such a correlation. Coupled with our previous observation that a subset of hippocampal PPAR $\gamma$ target genes are also CREB/CBP target genes (Denner et al., 2012), which are known to be regulated by ERK MAPK during memory consolidation (Guzowski and McGaugh, 1997; Ahi et al., 2004), these data suggest that PPAR $\gamma$ participation in a pERK complex may serve a compensatory role to re-establish proper ERK signaling that is disrupted by AD pathology. Previous studies found reduced levels of ERK2 protein and mRNA in AD hippocampus compared with controls (Trojanowski et al., 1993; Hyman et al., 1994), suggesting that the observed reduced interaction between PPAR $\gamma$ and $\mathrm{pERK}$ as AD progresses may result from an overall reduction in hippocampal ERK. Our previous bioinformatics analysis of transcriptomic and proteomic data from Tg2576 hippocampus following RSG treatment identified ERK signaling components and placed ERK as a central node in the signaling networks identified with cognitive enhancement (Denner et al., 2012). Thus, PPAR $\gamma$ agonism may serve to re-establish not only ERK2 levels, but also the dynamic range for ERK activation (e.g., recruitment of MEK) during memory consolidation.

Nuclear receptor interaction with ERK is not unprecedented as exemplified by the estrogen (Hashimoto et al., 2012), glucocorticoid (Strawhecker et al., 1989; Revest et al., 2005), and progesterone (Vicent et al., 2009) receptors. It is also becoming evident that ERK can be regulated through protein-protein interactions via well defined protein motifs. ERK has been shown to interact with numerous proteins, including Elk-1 and p90rsk (Sheridan et al., 2008), through both ERK-exclusive docking sites, known as DEF sites and defined by an FX(F/Y)P amino acid motif and generally located the $\mathrm{C}$ terminus to an ERK phosphorylation site (Sheridan et al., 2008), and the more general MAPK recognition $\mathrm{D}$ sites, defined by the amino acid sequence $\mathrm{K} / \mathrm{R} \mathrm{K} / \mathrm{R}$ K/R X ${ }_{(1-5)}$ L/I X L/I (Reményi et al., 2005; Garai et al., 2012).

We identified putative DEF and $\mathrm{D}$ sites within the $\mathrm{N}$ terminus of PPAR $\gamma$ at amino acids FHYG $_{119-122}$ and RRTIRLKL ${ }_{136-143}$, respectively. It is noteworthy that proteins that contain both $\mathrm{D}$ and DEF sites generally exhibit more specific and higher-affinity interaction with ERK than those that contain only one of the sites (Jacobs et al., 1999). That PPAR $\gamma$ contains consensus sequences, which are predicted to mediate direct interaction with ERK, provides a potential mechanism for their interaction during cognitive enhancement. Further, binding of proteins to the $\mathrm{N}$ terminus of nuclear receptors stabilizes the intrinsic disorder of this domain (Khan et al., 2012), suggesting an additional mechanism whereby pERK may facilitate complex stability by conferring order to the PPAR $\gamma$ N-terminal domain.

Our finding that PPAR $\gamma$ association with pERK in vivo was increased in RSG-treated Tg2576 mice only during memory consolidation suggests a dynamic ligand-dependent (RSG) mechanism for recruitment of pERK and other signaling partners (e.g., MEK and p90RSK). The conformational change conferred upon PPAR $\gamma$ through ligand binding (Choi et al., 2011) may make the ERK docking domains within PPAR $\gamma$ more accessible and could therefore increase the binding. Furthermore, ERK interacts with substrate DEF sites via a hydrophobic pocket adjacent to the kinase active site cleft (Lee et al., 2004) that is exposed fol- lowing MEK phosphorylation (Canagarajah et al., 1997). This phosphorylation-induced conformational change in ERK may account for our observation of a direct interaction in in vitro reconstitution studies between recombinant PPAR $\gamma$ and pERK2 that was not recapitulated with nonphosphorylated ERK2. Together, our data suggest that PPAR $\gamma$ and pERK directly interact in vitro and in vivo, and that this interaction contributes to cognitive enhancement with RSG treatment.

Since PPAR $\gamma$ agonism improved performance in an ERKdependent learning and memory task, and since PPAR $\gamma$ has a higher affinity for phosphorylated ERK compared with nonphosphorylated ERK, MEK is likely an important mediator of PPAR $\gamma$-pERK recruitment. While our studies did not directly address the involvement of MEK, our findings do indicate that MEK is likely a dynamic component of the PPAR $\gamma-$ pERK complex, since we detected increased steady-state MEK in pERK immunoprecipitation material from RSG-treated Tg2576 hippocampus yet decreased MEK when we probed pERK immunoprecipitation material at the $4 \mathrm{~h}$ memory consolidation time point (data not shown). In addition, MEK has been demonstrated to shuttle both ERK and PPAR $\gamma$ between nuclear and cytosolic compartments (Burgermeister and Seger, 2007), suggesting that MEK may regulate PPAR $\gamma$-pERK complex localization. Alternatively, PPAR $\gamma-$ pERK association may facilitate the downstream activity of pERK through improved pERKdependent phosphorylation activation of Elk-1 and p90RSK (Frödin and Gammeltoft, 1999; Ahi et al., 2004).

Memory formation begins with an acquisition phase followed by a consolidation phase in the ensuing hours to form a memory trace that can be retrieved at a later time. ERK phosphorylation is required for memory through transcriptional regulation of target genes essential for coding a new memory trace. In the Tg2576 model of $\mathrm{AD}, \mathrm{ERK}$ is dysregulated and unable to properly function in new memory formation. Thus, we propose a model in which ligand-activated $\operatorname{PPAR} \gamma$ restores dysfunctional ERKdependent signaling to facilitate memory consolidation through the recruitment of binding partners to a pERK multiprotein complex (Fig. 6). One potential binding partner in this process is the histone acetyltransferase CBP, which serves as a transcriptional cofactor for both CREB and PPAR $\gamma$ (Vecsey et al., 2007; Bugge et al., 2009), and may be a convergent central node between the PPAR $\gamma$ and ERK pathways (Denner et al., 2012). The identification of these novel PPAR $\gamma-$ pERK complexes provides unique opportunities for newly targeted therapeutics to improve memory in $\mathrm{AD}$ and warrants further investigation.

\section{References}

Ahi J, Radulovic J, Spiess J (2004) The role of hippocampal signaling cascades in consolidation of fear memory. Behav Brain Res 149:17-31. CrossRef Medline

Atkins CM, Selcher JC, Petraitis JJ, Trzaskos JM, Sweatt JD (1998) The MAPK cascade is required for mammalian associative learning. Nat Neurosci 1:602-609. CrossRef Medline

Becker RE, Greig NH (2013) Fire in the ashes: can failed Alzheimer's disease drugs succeed with second chances? Alzheimers Dement 9:50-57. CrossRef Medline

Bjorklund NL, Sadagoparamanujam VM, Taglialatela G (2012) Selective, quantitative measurement of releasable synaptic zinc in human autopsy hippocampal brain tissue from Alzheimer's disease patients. J Neurosci Methods 203:146-151. CrossRef Medline

Bugge A, Grøntved L, Aagaard MM, Borup R, Mandrup S (2009) The PPAR-gamma2 a/B-domain plays a gene-specific role in transactivation and cofactor recruitment. Mol Endocrinol 23:794-808. CrossRef Medline

Burgermeister E, Seger R (2007) Mapk kinases as nucleo-cytoplasmic shuttles for Ppargamma. Cell Cycle 6:1539-1548. CrossRef Medline 
Canagarajah BJ, Khokhlatchev A, Cobb MH, Goldsmith EJ (1997) Activation mechanism of the map kinase Erk2 by dual phosphorylation. Cell 90:859-869. CrossRef Medline

Choi JH, Banks AS, Kamenecka TM, Busby SA, Chalmers MJ, Kumar N, Kuruvilla DS, Shin Y, He Y, Bruning JB, Marciano DP, Cameron MD, Laznik D, Jurczak MJ, Schurer SC, Vidović D, Shulman GI, Spiegelman BM, Griffin PR (2011) Antidiabetic actions of a non-agonist Ppargamma ligand blocking Cdk5-mediated phosphorylation. Nature 477: 477-481. CrossRef Medline

Clark WG, Vivonia CA, Baxter CF (1968) Accurate freehand injection into the lateral brain ventricle of the conscious mouse. J Appl Physiol 25:319321. Medline

Cohen J (1992) A power primer. Psychol Bull 112:155-159. CrossRef Medline

Craft S (2012) Alzheimer disease: insulin resistance and AD—extending the translational path. Nat Rev Neurol 8:360-362. CrossRef Medline

Craft S, Baker LD, Montine TJ, Minoshima S, Watson GS, Claxton A, Arbuckle M, Callaghan M, Tsai E, Plymate SR, Green PS, Leverenz J, Cross D, Gerton B (2012) Intranasal insulin therapy for Alzheimer disease and amnestic mild cognitive impairment: a pilot clinical trial. Arch Neurol 69:29-38. CrossRef Medline

Denner LA, Rodriguez-Rivera J, Haidacher SJ, Jahrling JB, Carmical JR, Hernandez CM, Zhao Y, Sadygov RG, Starkey JM, Spratt H, Luxon BA, Wood TG, Dineley KT (2012) Cognitive enhancement with rosiglitazone links the hippocampal PPAR $\gamma$ and ERK MAPK signaling pathways. J Neurosci 32:16725-16735a. CrossRef Medline

Dineley KT, Xia X, Bui D, Sweatt JD, Zheng H (2002) Accelerated plaque accumulation, associative learning deficits, and up-regulation of Alpha 7 nicotinic receptor protein in transgenic mice co-expressing mutant human presenilin 1 and amyloid precursor proteins. J Biol Chem 277: 22768-22780. CrossRef Medline

Dineley KT, Hogan D, Zhang WR, Taglialatela G (2007) Acute inhibition of calcineurin restores associative learning and memory in Tg2576 APP transgenic mice. Neurobiol Learn Mem 88:217-224. CrossRef Medline

Escribano L, Simón AM, Pérez-Mediavilla A, Salazar-Colocho P, Del Río J, Frechilla D (2009) Rosiglitazone reverses memory decline and hippocampal glucocorticoid receptor down-regulation in an Alzheimer's disease mouse model. Biochem Biophys Res Commun 379:406-410. CrossRef Medline

Frödin M, Gammeltoft S (1999) Role and regulation of $90 \mathrm{kDa}$ ribosomal S6 kinase (Rsk) in signal transduction. Mol Cell Endocrinol 151:65-77. CrossRef Medline

Garai Á, Zeke A, Gógl G, Törő I, Fördős F, Blankenburg H, Bárkai T, Varga J, Alexa A, Emig D, Albrecht M, Reményi A (2012) Specificity of linear motifs that bind to a common mitogen-activated protein kinase docking groove. Sci Signal 5:ra74. CrossRef Medline

Gavin AC, Nebreda AR (1999) A map kinase docking site is required for phosphorylation and activation of P90(Rsk)/MAPKAP kinase-1. Curr Biol 9:281-284. CrossRef Medline

Guzowski JF, McGaugh JL (1997) Antisense oligodeoxynucleotidemediated disruption of hippocampal camp response element binding protein levels impairs consolidation of memory for water maze training. Proc Natl Acad Sci U S A 94:2693-2698. CrossRef Medline

Hamann S, Monarch ES, Goldstein FC (2002) Impaired fear conditioning in Alzheimer's disease. Neuropsychologia 40:1187-1195. CrossRef Medline

Hashimoto R, Yu J, Koizumi H, Ouchi Y, Okabe T (2012) Ginsenoside Rb1 prevents $\operatorname{Mpp}(+)$-induced apoptosis in Pc12 cells by stimulating estrogen receptors with consequent activation of ERK1/2, Akt and inhibition of SAPK/Jnk, P38 MAPK. Evid Based Complement Alternat Med 2012: 693717. CrossRef Medline

Hoefer M, Allison SC, Schauer GF, Neuhaus JM, Hall J, Dang JN, Weiner MW, Miller BL, Rosen HJ (2008) Fear conditioning in frontotemporal lobar degeneration and Alzheimer's disease. Brain 131:1646-1657. CrossRef Medline

Hort J, Laczó J, Vyhnálek M, Bojar M, Bures J, Vlcek K (2007) Spatial navigation deficit in amnestic mild cognitive impairment. Proc Natl Acad Sci U S A 104:4042-4047. CrossRef Medline

Hsiao K, Chapman P, Nilsen S, Eckman C, Harigaya Y, Younkin S, Yang F, Cole G (1996) Correlative memory deficits, Abeta elevation, and amyloid plaques in transgenic mice. Science 274:99-102. CrossRef Medline

Hyman BT, Elvhage TE, Reiter J (1994) Extracellular signal regulated ki- nases. Localization of protein and MRNA in the human hippocampal formation in Alzheimer's disease. Am J Pathol 144:565-572. Medline

Jacobs D, Glossip D, Xing H, Muslin AJ, Kornfeld K (1999) Multiple docking sites on substrate proteins form a modular system that mediates recognition by Erk Map kinase. Genes Dev 13:163-175. CrossRef Medline

Jiang Q, Heneka M, Landreth GE (2008) The role of peroxisome proliferator-activated receptor-Gamma (Ppargamma) in Alzheimer's disease: therapeutic implications. CNS Drugs 22:1-14. CrossRef Medline

Khan SH, Awasthi S, Guo C, Goswami D, Ling J, Griffin PR, Simons SS Jr, Kumar R (2012) Binding of the N-terminal region of coactivator Tif2 to the intrinsically disordered Af1 domain of the glucocorticoid receptor is accompanied by conformational reorganizations. J Biol Chem 287: 44546-44560. CrossRef Medline

Landreth G, Jiang Q, Mandrekar S, Heneka M (2008) Ppargamma agonists as therapeutics for the treatment of Alzheimer's disease. Neurotherapeutics 5:481-489. CrossRef Medline

Lee T, Hoofnagle AN, Kabuyama Y, Stroud J, Min X, Goldsmith EJ, Chen L, Resing KA, Ahn NG (2004) Docking motif interactions in Map kinases revealed by hydrogen exchange mass spectrometry. Mol Cell 14:43-55. CrossRef Medline

Mandrekar-Colucci S, Landreth GE (2011) Nuclear receptors as therapeutic targets for Alzheimer's disease. Expert Opin Ther Targets 15:1085-1097. CrossRef Medline

Mandrekar-Colucci S, Karlo JC, Landreth GE (2012) Mechanisms underlying the rapid peroxisome proliferator-activated receptor- $\gamma$-mediated amyloid clearance and reversal of cognitive deficits in a murine model of Alzheimer's disease. J Neurosci 32:10117-10128. CrossRef Medline

McGaugh JL (2000) Memory-a century of consolidation. Science 287: 248-251. CrossRef Medline

Miyamoto-Sato E, Fujimori S, Ishizaka M, Hirai N, Masuoka K, Saito R, Ozawa Y, Hino K, Washio T, Tomita M, Yamashita T, Oshikubo T, Akasaka H, Sugiyama J, Matsumoto Y, Yanagawa H (2010) A comprehensive resource of interacting protein regions for refining human transcription factor networks. PLoS One 5:e9289. CrossRef Medline

Morice E, Farley S, Poirier R, Dallerac G, Chagneau C, Pannetier S, Hanauer A, Davis S, Vaillend C, Laroche S (2013) Defective synaptic transmission and structure in the dentate gyrus and selective fear memory impairment in the Rsk2 mutant mouse model of Coffin-Lowry syndrome. Neurobiol Dis 58:156-168. CrossRef Medline

Paxinos G, Watson C, Pennisi M, Topple A (1985) Bregma, lambda and the interaural midpoint in stereotaxic surgery with rats of different sex, strain and weight. J Neurosci Methods 13:139-143. CrossRef Medline

Pedersen WA, McMillan PJ, Kulstad JJ, Leverenz JB, Craft S, Haynatzki GR (2006) Rosiglitazone attenuates learning and memory deficits in Tg2576 Alzheimer mice. Exp Neurol 199:265-273. CrossRef Medline

Reményi A, Good MC, Bhattacharyya RP, Lim WA (2005) The role of docking interactions in mediating signaling input, output, and discrimination in the yeast MAPK network. Mol Cell 20:951-962. CrossRef Medline

Revest JM, Di Blasi F, Kitchener P, Rougé-Pont F, Desmedt A, Turiault M, Tronche F, Piazza PV (2005) The MAPK pathway and Egr-1 mediate stress-related behavioral effects of glucocorticoids. Nat Neurosci 8:664672. CrossRef Medline

Risner ME, Saunders AM, Altman JF, Ormandy GC, Craft S, Foley IM, Zvartau-Hind ME, Hosford DA, Roses AD (2006) Efficacy of rosiglitazone in a genetically defined population with mild-to-moderate Alzheimer's disease. Pharmacogenomics J 6:246-254. CrossRef Medline

Rodriguez-Rivera J, Denner L, Dineley KT (2011) Rosiglitazone reversal of $\operatorname{Tg} 2576$ cognitive deficits is independent of peripheral gluco-regulatory status. Behav Brain Res 216:255-261. CrossRef Medline

Ryan KK, Li B, Grayson BE, Matter EK, Woods SC, Seeley RJ (2011) A role for central nervous system PPAR-gamma in the regulation of energy balance. Nat Med 17:623-626. CrossRef Medline

Sato T, Hanyu H, Hirao K, Kanetaka H, Sakurai H, Iwamoto T (2011) Efficacy of PPAR-gamma agonist pioglitazone in mild Alzheimer disease. Neurobiol Aging 32:1626-1633. CrossRef Medline

Selcher JC, Nekrasova T, Paylor R, Landreth GE, Sweatt JD (2001) Mice lacking the ERK1 isoform of MAP kinase are unimpaired in emotional learning. Learn Mem 8:11-19. CrossRef Medline

Shalin SC, Zirrgiebel U, Honsa KJ, Julien JP, Miller FD, Kaplan DR, Sweatt JD (2004) Neuronal MEK is important for normal fear conditioning in mice. J Neurosci Res 75:760-770. CrossRef Medline

Sheridan DL, Kong Y, Parker SA, Dalby KN, Turk BE (2008) Substrate dis- 
crimination among mitogen-activated protein kinases through distinct docking sequence motifs. J Biol Chem 283:19511-19520. CrossRef Medline

Smith JA, Poteet-Smith CE, Malarkey K, Sturgill TW (1999) Identification of an extracellular signal-regulated kinase (ERK) docking site in ribosomal S6 kinase, a sequence critical for activation by ERK in vivo. J Biol Chem 274:2893-2898. CrossRef Medline

Sperling RA, Aisen PS, Beckett LA, Bennett DA, Craft S, Fagan AM, Iwatsubo T, Jack CR Jr, Kaye J, Montine TJ, Park DC, Reiman EM, Rowe CC, Siemers E, Stern Y, Yaffe K, Carrillo MC, Thies B, Morrison-Bogorad M, Wagster MV, et al. (2011) Toward defining the preclinical stages of Alzheimer's disease: recommendations from the National Institute on Aging-Alzheimer's Association Workgroups on Diagnostic Guidelines for Alzheimer's Disease. Alzheimers Dement 7:280-292. CrossRef Medline

Stockhorst U, de Fries D, Steingrueber HJ, Scherbaum WA (2004) Insulin and the CNS: effects on food intake, memory, and endocrine parameters and the role of intranasal insulin administration in humans. Physiol Behav 83:47-54. CrossRef Medline

Strawhecker JM, Betz NA, Neades RY, Houser W, Pelling JC (1989) Binding of the $97 \mathrm{kDa}$ glucocorticoid receptor to the $5^{\prime}$ upstream flanking region of the mouse C-Ha-Ras oncogene. Oncogene 4:1317-1322. Medline

Sweatt JD (2004) Mitogen-activated protein kinases in synaptic plasticity and memory. Curr Opin Neurobiol 14:311-317. CrossRef Medline

Taglialatela G, Hogan D, Zhang WR, Dineley KT (2009) Intermediate- and long-term recognition memory deficits in Tg2576 mice are reversed with acute calcineurin inhibition. Behav Brain Res 200:95-99. CrossRef Medline

Talbot K, Wang HY, Kazi H, Han LY, Bakshi KP, Stucky A, Fuino RL, Kawaguchi KR, Samoyedny AJ, Wilson RS, Arvanitakis Z, Schneider JA, Wolf BA, Bennett DA, Trojanowski JQ, Arnold SE (2012) Demonstrated brain insulin resistance in Alzheimer's disease patients is associated with IGF-1 resistance, Irs-1 dysregulation, and cognitive decline. J Clin Invest 122:1316-1338. CrossRef Medline

Thies W, Bleiler L (2013) 2013 Alzheimer's disease facts and figures. Alzheimers Dement 9:208-245. CrossRef Medline

Trifilieff P, Calandreau L, Herry C, Mons N, Micheau J (2007) Biphasic Erk1/2 activation in both the hippocampus and amygdala may reveal a system consolidation of contextual fear memory. Neurobiol Learn Mem 88:424-434. CrossRef Medline
Trojanowski JQ, Mawal-Dewan M, Schmidt ML, Martin J, Lee VM (1993) Localization of the mitogen activated protein kinase ERK2 in Alzheimer's disease neurofibrillary tangles and senile plaque neurites. Brain Res 618: 333-337. CrossRef Medline

van Himbergen TM, Beiser AS, Ai M, Seshadri S, Otokozawa S, Au R, Thongtang N, Wolf PA, Schaefer EJ (2012) Biomarkers for insulin resistance and inflammation and the risk for all-cause dementia and Alzheimer disease: results from the Framingham Heart Study. Arch Neurol 69:594600. CrossRef Medline

Vecsey CG, Hawk JD, Lattal KM, Stein JM, Fabian SA, Attner MA, Cabrera SM, McDonough CB, Brindle PK, Abel T, Wood MA (2007) Histone deacetylase inhibitors enhance memory and synaptic plasticity via CREB: CBP-dependent transcriptional activation. J Neurosci 27:6128-6140. CrossRef Medline

Vicent GP, Zaurin R, Ballaré C, Nacht AS, Beato M (2009) ERK signaling and chromatin remodeling in MMTV promoter activation by progestins. Nucl Recept Signal 7:e008. CrossRef Medline

von Kriegsheim A, Baiocchi D, Birtwistle M, Sumpton D, Bienvenut W, Morrice N, Yamada K, Lamond A, Kalna G, Orton R, Gilbert D, Kolch W (2009) Cell fate decisions are specified by the dynamic ERK interactome. Nat Cell Biol 11:1458-1464. CrossRef Medline

Watson GS, Craft S (2004) Modulation of memory by insulin and glucose: neuropsychological observations in Alzheimer's disease. Eur J Pharmacol 490:97-113. CrossRef Medline

Watson GS, Cholerton BA, Reger MA, Baker LD, Plymate SR, Asthana S, Fishel MA, Kulstad JJ, Green PS, Cook DG, Kahn SE, Keeling ML, Craft S (2005) Preserved cognition in patients with early Alzheimer disease and amnestic mild cognitive impairment during treatment with rosiglitazone: a preliminary study. Am J Geriatr Psychiatry 13:950-958. Medline

Westerman MA, Cooper-Blacketer D, Mariash A, Kotilinek L, Kawarabayashi T, Younkin LH, Carlson GA, Younkin SG, Ashe KH (2002) The relationship between $A \beta$ and memory in the $\operatorname{Tg} 2576$ mouse model of Alzheimer's disease. J Neurosci 22:1858-1867. Medline

Wu Z, Rosen ED, Brun R, Hauser S, Adelmant G, Troy AE, McKeon C, Darlington GJ, Spiegelman BM (1999) Cross-regulation of C/Ebp alpha and Ppar gamma controls the transcriptional pathway of adipogenesis and insulin sensitivity. Mol Cell 3:151-158. CrossRef Medline

Yoon S, Seger R (2006) The extracellular signal-regulated kinase: multiple substrates regulate diverse cellular functions. Growth Factors 24:21-44. CrossRef Medline 